\title{
Анизотропный световод типа «Панда» с фосфорогерманосиликатной сердщевиной, легированной висмутом
}

В.В. Вельмискин ${ }^{1, *}$, А.Н. Денисов ${ }^{1}$, К.Е. Рюмкин ${ }^{1}$, С.В. Фирстов ${ }^{1}$, А.М. Хегай ${ }^{1}$, М.А. Мелькумов ${ }^{1}$, Ф.В. Афанасьев ${ }^{2}$, Е.М. Дианов ${ }^{1}$

${ }^{1}$ Научный ичентр волоконной оптики РАН

${ }^{2}$ Институт химии высокочистых вещчеств им. Г.Г. Девятых РАН

*E-mail: vvv@fo.gpi.ru

DOI:10.31868/RFL2018.104-105

В данной работе разработан и изготовлен активный анизотропный световод типа «Панда» с фосфорогерманосиликатной сердцевиной, легированной висмутом, представлены основные волноводные и усилительные характеристики и определены области применения.

Легирование фосфоросилкитной матрицы стекла висмутом приводит к формированию активных центров, ответственных за люминесценцию и усиление в области 1,3 мкм [1]. На световодах с такой сердцевиной было реализовано большое количество лазерных устройств включая непосредственно импульсные и непрерывные лазеры, оптические усилители и суперлюминесцентные волоконные источники излучения [2]. Для расширения сферы применения такой активной среды и проведения дополнительных исследований перспективно изготовление анизотропных активных световодов.

Наиболее оптимальным способом изготовления активного анизотропного световода, легированного висмутом, в нашем случае является технология «Панда» [3]. Материнская заготовка световода была изготовлена методом MCVD, разница показателей преломления сердцевины и оболочки $\Delta \mathrm{n}=5,5 \times 10^{-3}$, концентрация висмута в сердцевине менее 0,1 мас.\%. Заготовка была перетянута до 11,5 мм для изотовления сборки, в ней были просверлены отверстия на расстоянии 2,6 мм от центра с диаметром 3,7 мм. В данные отверстия были вставлены стержни из боросиликатного стекла, затем была сплавлена общая заготовка и вытянут волоконный световод.

Фотография торца вытянутого световода представлена на Рис. 1(а). Были измерены анизотропные характеристики световода, разность показателей преломления для перпендикулярных мод составила $\approx 10^{-4}$, что сопоставимо с параметрами коммерческих активных анизотропных световодов.

(a)

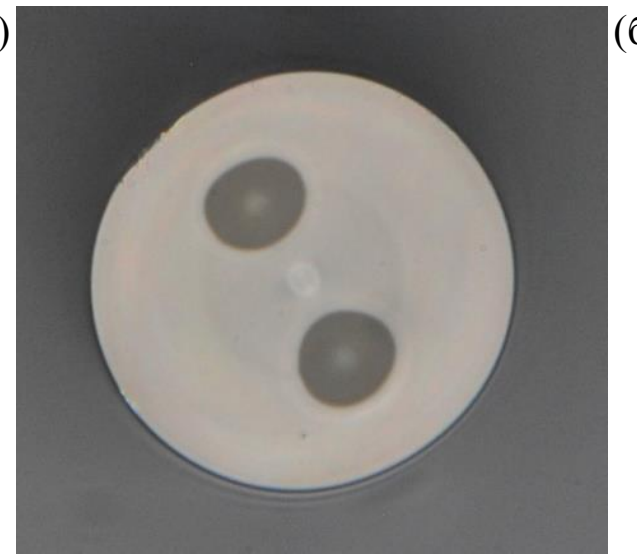

(б)

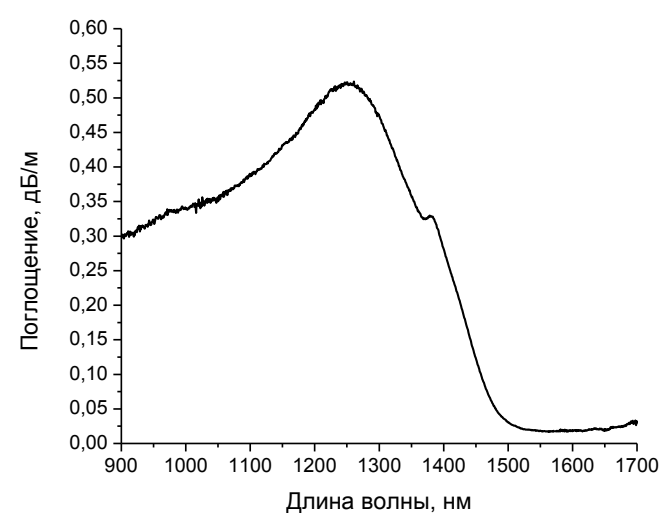

Рис.1. Фотография торца (а) и спектр поглощения (б) световода. 
Спектр поглощения световода представлен на Рис.1(б). Поглощение на длине 1240 нм составляет 0,52 дБ/м и является типичным для эффективных активных фосфоросиликатных световодов, легированных висмутом.

(a)

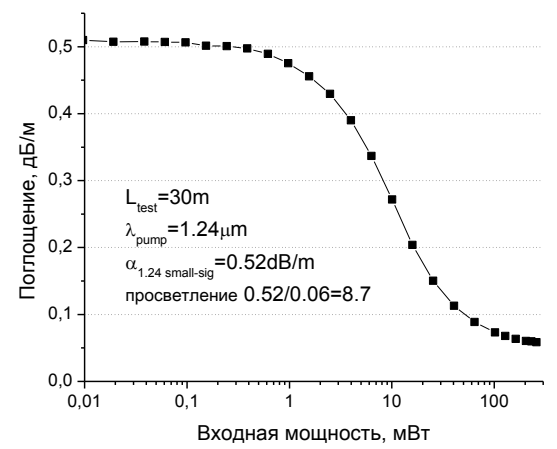

(б)

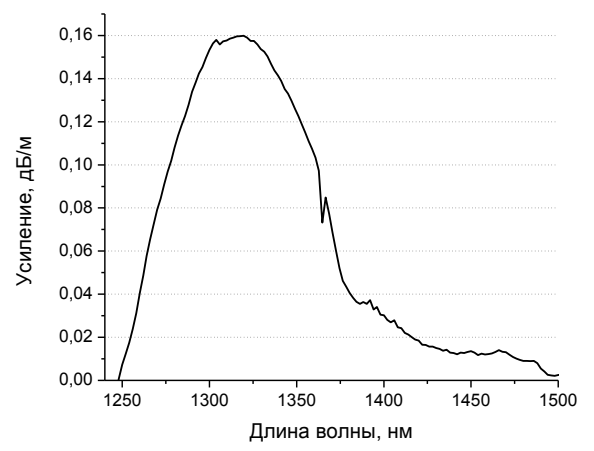

Рис.2. Просветление (а) и спектр усиления (б) световода.

В световоде было измерено просветление сигнала на длине волны накачки 1240 нм (Рис. 2(а)). Поглощение большого сигнала составляет 0,06 дБ/м при малом 0,52 дБ/м. Таким образом световод просветляется в 8,7 раз, что является приемлемым для световодов такого типа. Спектр усиления световода (Рис. 2(б)) также сопоставим с типичными спектрами усиления изотропных висмутовых световодов. Таких образом введение стержней и наведение анизотропии не ухудшило оптические и усилительные свойства световода.

Такой активный световод незаменим в волоконно-оптических лазерах с синхронизацией мод и в любых специализированных применениях, требующих активную среду с поддержкой распространения определенной поляризации, он будет использован для изготовления лазерных устройств в последующих работах. Также на данном световоде планируется проведение исследований влияния поляризации накачки и сигнала на усиление, данные исследования будут полезны как с фундаментальной точки зрения, поскольку позволят получить новые знания о висмутовых центрах, так и с практической, поскольку важны при проектировании лазерных устройств.

Исследование выполнено при финансовой поддержке РФФИ в рамках научного проекта № 18-32-00927.

\section{Литература}

[1] S.V. Firstov, I.A. Bufetov et al., Laser Physics Letters, 6, 665-670 (2009)

[2] I. A. Bufetov, M. A. Melkumov et al., IEEE J. Sel. Top. Quantum Electron., 20, 111 (2014)

[3] J. Noda, K. Okamoto et al., J. Lightwave Technol., 4, 1071 (1986) 